\title{
Examination of University Students' Attitudes towards E-learning during the COVID-19 Pandemic Process and the Relationship of Digital Citizenship
}

\author{
Umut Akcil \\ Faculty of Education at Near East University, Nicosia, CYPRUS \\ ORCID: 0000-0002-5703-9630 \\ Mert Bastas \\ Faculty of Education at Near East University, Nicosia, CYPRUS \\ ORCID: 0000-0001-5149-5451
}

Received: 24 Jul 2020

Accepted: 26 Nov 2020

\begin{abstract}
The COVID-19 pandemic has had an impact on people's social interaction and has brought changes on education, environment and economy. COVID-19, which affects every aspect of life, has produced results that require re-evaluating the perspective on education. Distance learning, digital learning, e-learning has reshaped education in many ways. There can be a chance of the pandemic in the digital age to turn into an advantage for the education sector. In this period, it can be said that those who have high interest in technology move more easily in distance education and e-learning processes. In this context, expressing the best skills in the digital age, it was thought that the concept of digital citizenship would have positive effects on e-learning. This study is a relational survey and tested by establishing a relationship between digital citizenship and e-learning. The study was conducted among higher education students. It has been observed that there is a positive relationship between digital citizenship behaviors and e-learning attitudes. In addition, it has been observed that the negative anxiety of students due to the pandemic is reflected in their e-learning processes. However, overall results show that digital citizenship behavior digital learning process could be a positive response to COVID-19 closure period.
\end{abstract}

Keywords: COVID-19 pandemic, e-learning, digital citizenships, digital age, higher education

\section{INTRODUCTION}

It is a well-known fact that pandemics have had negative impacts throughout history (WHO, 2020a). Today we are facing a new pandemic. In late 2019, Coronavirus-SARS-COV-2 virus was detected in the city of Wuhan, China. It can be said based on the data of the world health organization that the COVID-19 pandemic, together with its rapid spreading power, affected almost the entire world in a very short time (WHO, 2020b, 2020c).

With the outbreak of the pandemic, partial or full time curfews have been imposed around the world. It is observed that individuals are taking measures such as isolating themselves or protecting social distance. In order to reduce the contagion and spreading effect of the epidemic that changed the flow of life, practices such as flexible working, working from home, and working in rotations have been implemented (Zhao, 2020). Within the framework of these measures, the education sector also has had to comply with the restrictions imposed. It seems that education has come to a stop. UNESCO has announced that 1.6 billion students, 
representing half of the student population at all educational levels globally, are unable to continue their education (UNESCO, 2020).

Due to the chaos created by COVID-19 pandemic, governments took steps to protect their citizens and economies. They also adopted urgent measures about the usage of digital technologies. The most prominent of these measures is the transfer of education processes to digital media (Agnoletto \& Queiroz, 2020). During the COVID-19 pandemic, it is expected that whole academic years will be maintained in digital environments (Mulenga \& Marban, 2020).

Due to the disruption of face-to-face education in schools, administrators, teachers and students alike have had to use various education management systems and teaching technologies continuously in the education and training process. Due to the COVID-19 pandemic these technologies have become indispensable for education and training processes. The COVID-19 pandemic has been a catalyst for more effective use of digital devices, online resources, social media technology and e-learning activities (Basilaia, \& Kvavadze, 2020; Demuyakor, 2020; Lounis, 2020; Mulenga \& Marban, 2020; Murphy et al., 2020; Mutua \& Ong'ong'a, 2020).

Distance education and e-learning services are based on the use of a wide range of technologies from primary and secondary education to higher education level, from in-service education and foreign language teaching to the education of persons with disabilities (Simonson et al., 1999).

In the light of the developments, we are closely witnessing the reflections of digital age. Today it is almost impossible to realize education without using education and teaching technologies (Sarsıcı \& Çelik, 2019). The facilities experienced with the development of information communication technologies, distance education applications that further support education in the digital environment have become more important than ever.

One of the most observed situations during COVID-19 pandemic is that solutions based on online education technologies have been put into effect rapidly so as to ensure e-learning within the scope of distance education. In the current process, further disrupting of education is unacceptable as the consequences of stopping or disrupting education today will be reflected to the future lives of individuals by far the best. Therefore, flexible learning environments are needed to minimize the resulting negative situation (Daniel, 2020). The use of many new learning approaches, such as virtual learning, e-learning, online learning, mobile learning, synchronous-asynchronous learning, that can protect people's health and take into account social distances has increased.

It is seen that mostly new learning experiences have emerged which occur at internet-assisted digital environments (Crawford, 2009). The widespread use of these modern learning platforms is mainly due to the opportunities they provide. However, with this rapid development in the world of technology, it has become inevitable to improve technology usage skills so as to reach knowledge in the field of education (Akçıl et al., 2019). While individuals with these skills were referred to as technology leaders in the past, the concept of "digital citizenship behaviors", which expresses a higher level of gain beyond this, is seen more important today.

Technology leadership, or in other words, e-leadership, is about a person's level of technology usage for a particular subject and work (Avolio et al., 2000). On the other hand, digital citizenship is about transferring basic rights, responsibilities and duties to digital environment and living with these high-level norms in digital environments (Karaatmaca et al., 2020). Digital citizenship is briefly referred to as the acquisition and implementation of responsible behavioral norms related to the usage of technology (Rible \& Bailey, 2007).

The new approaches that emerged in the COVID-19 period and the digital age once again brought to the agenda can be seen as an opportunity for education sectors. In addition, it should not be forgotten that the effects of the mentioned approaches are being tested in the natural environment of the pandemic process. 


\section{Distance Education and E-learning}

With the information and communication technologies we use today, information constantly changes place in electronic media and continues its journey. If we are to think this journey within the scope of education and teaching, we come up with distance education and accompanying e-learning (electronic learning) concepts. E-learning is actually a concept included in the concept of distance education (Urdan and Weggen 2000). For this reason, it will be useful to define the concept of distance education before explaining the concept of e-learning.

Distance education is an institutional education activity where students, teachers and teaching materials in different places are brought together through information communication technologies (Moore \& Kearsley (1996). It is stated that the restrictions in traditional education are eliminated and it is an education model that is realized without time and place restrictions by means of information and communication technologies (Demir, 2014). Distance education activities, which were carried out by means of letters, telephones, and radio-television in the past, have gained momentum with the development of information communication technologies since the 1990s, thanks to "Web" and "Internet" technologies (Casey, 2008).

E-learning in the simplest way can be defined as performance of teaching activities in electronic media and transfer of information and skills through electronic technologies (Gülbahar, 2012). Rosenberg (2001) defines e-learning process as "the use of internet technologies in accessing information and creating it". Especially with the increase of internet technologies, it is also expressed as web-based education-oriented activities (Muhammed et al., 2016).

Unlike traditional education, e-learning has many advantages that make e-learning environments attractive to students, such as flexibility, speed, time savings, and cost reduction through information communication technologies and the internet (Naved et al., 2017). In addition, it is a learning process that is applied in cases where education cannot be continued in a school building.

Self-learning on the basis of distance education, technology and information literacy, foreign language, digital citizenship, adaptation to changing conditions and following up-to-date information are important capabilities in raising the human profile needed in the $21^{\text {st }}$ century (FIrat, 2016).

\section{Digital Citizenship}

Mossberger, Tolbert and McNeal (2007) define "digital citizen" as a person who knows how to accurately use technology and digital devices which entered our lives with it, shows respect to ethical rules and individual rights at digital platform, and knows how to use these devices safely with a sense of responsibility. Considering the actions taking place in digital environments, citizens have to be aware of their responsibilities not only towards the society they live in but also to the entire world. In this way, it can be said that individuals can continue their lives in the digital age safely through digital citizenship behaviors (Akcil et al., 2016).

Digital citizenship and its approach generally provides advice to students, educators and industry representatives in the context of the technological needs of students, especially in terms of conscious and correct use of online technologies and other digital platforms (Çubukcu \& Bayzan, 2013). These recommendations were first considered by Ribble (2011), and created 9 sub-dimensions of "Digital Citizenship". These dimensions are expressed as digital literacy, digital interaction, digital communication, digital safety, digital ethics, digital rights and responsibilities, digital law, digital commerce and digital health.

Digital interaction can be defined as the level of citizens who access a lot of useful-harmful information in online environments to be able to perform successful analyzes about this information they access in relevant environments (Çubukcu \& Bayzan, 2013); digital safety can be defined as not knowing what security measures to take when using devices with access (Ribble \& Bailey 2007); digital literacy can be defined as people's knowledge about digital tools and their use, the correct use of the internet, the effort to reach the right information, and their behavior about sharing the right information (Ribble \& Bailey, 2007); digital communication is defined as using the right to communicate in internet media, displaying correct attitude in one's sharing and cooperation (Belonovskaya et al., 2020; Çubukcu \& Bayzan, 2013); digital ethics can be 
defined as management of behaviors as regards how technology should be used (Ribble, 2011); digital law can be defined as citizens acting with the conscious that all criminal actions in real life are also criminal in digital media (Çubukcu \& Bayzan, 2013); digital rights and responsibilities can be defined as everyone freely expressing themselves through information tools, individuals using information tools and the internet to behave responsibly towards themselves and other people (Ribble \& Bailey, 2007); digital health can be defined as to recognize the problems in the field of health that may occur with the use of digital technologies and to be able to take necessary measures (Kocadağ, 2012); digital commerce can be defined as the ability to perform commercial activities today through internet network (Ünal, 2017).

It is stated that new sub-dimensions have been added to the citizenship skills described above and that the digital citizenship field has expanded further. Alberta (2012) suggested adding two new sub-dimensions for digital citizenship, cloud computing, and the use of digital tools such as smart phones, laptops, and tablets. Akçll et al. (2016) conducted a study by adding the relevant dimensions. This study showed that the use of cloud computing storage areas and the use of portable devices can be added as sub-dimensions.

As can be seen, each of the 9 items and the 2 additional items listed above include norms that digital citizens should possess in digital world. Regardless of the circumstances, these behaviors should be possessed in the transition to digital world. Especially in distance education, which is one of the most important elements of digital world, possession of these behaviors is essential for participating in e-learning processes with sufficient level of responsibility as well as acquiring expected behaviors, reaching information accurately, and using this information.

\section{COVID-19 and E-learning Process}

In the studies conducted in 2020, it is revealed that there are still deficiencies in the correct and responsible use of technology in the education sector during the COVID-19 pandemic process. Burke and Dempsey (2020) identified through e-mails and phone conversations the deficiencies of students, parents, teachers and other personnel in maintaining communication from distance and argued that measures should be taken in this regard. Gong (2020) expressed that among the obstacles in distance education is the lack of safety of access to internet and internet-featured devices and that some measures should be taken in this regard. In their study, Sarı and Nayır (2020) stated that parents and teachers who were caught unprepared for distance education and e-teaching during the COVID-19 epidemic experienced difficulties in creating, maintaining and developing distance learning, and teachers and students could not demonstrate the level of technology usage expected from them. Deshmukh (2020) stated in a similar study that the digital competence and skills needed in the pandemic process could not be obtained. In another study, it is also mentioned that digital footprints are formed rapidly with the pandemic, but there is no detailed action to protect this body of data (Teräs et al., 2020). It is observed that both educators and students and parents experience a panic in using online platforms.

As a result of the studies mentioned above, the problems and panic experienced can be attributed to the fact that adequate digital citizenship behaviors do not exist, or that this concept is not taken into consideration or adopted adequately. In addition, it should not be forgotten that anxiety, stress, chaos and uncertainty experienced today can affect individuals negatively.

If students have the competence to use the necessary technology environments and digital citizenship behaviors in the distance education process today, they will be able to get rid of this negative psychology and their attitude towards e-learning will be more positive. As Agnoletto and Queiroz (2020) stated, the necessity to act fast, to gain familiarity with online teaching tools, to provide fluency in the use of digital tools, as well as to cope with fear and various negative emotions are among the basic needs in the pandemic process.

\section{Purpose of the Research}

It is known that in the current period, the education system has started to move from face-to-face education to partially, predominantly or completely online-based distance education. Especially in this period, when it is considered that distance education is more intense, the concept of digital citizenship draws attention. The 
reasons for this are detailed above. During the COVID 19 pandemic process, it is important to investigate how digital citizenship behaviors affect students' attitudes towards e-learning and to make inferences.

From this point of view, it was aimed to conduct the study at the level of university students by narrowing the field of research in order to carry out the research in a healthy way in studying this subject. Thus, it was aimed to investigate the relationship between the attitudes towards e-learning and digital citizenship behaviors of pre-service teachers who continue distance education in the COVID-19 process and to examine this relationship in terms of various variables. Research questions developed for this purpose are as follows:

1- What is the level of attitudes of students towards e-learning during the COVID-19 pandemic?

2- What is the level of the digital citizenship behaviors of students?

3- Is there a relationship between attitudes of students towards e-learning and their digital citizenship behaviors in the COVID-19 process?

4- During the COVID-19 pandemic process, do the attitudes of students towards e-learning vary according to their gender and grade level?

\section{METHOD}

The general purpose of this study is to examine the digital citizenship behaviors of students and their attitudes towards e-learning in terms of several variables and to determine the direction and level of correlation between these two variables. In this direction, this study was conducted using correlational survey method which is a qualitative research method. In quantitative studies, researchers identify a theory and test it with numbers or mathematical deductions. Survey model, on the other hand, enables the quantitative description of trends, attitudes or opinions across the universe through studies conducted on a sample (Creswell, 2011). Correlational survey model is a research model that aims to determine the presence and / or degree of covariance between two or more variables (Fraenkel \& Wallen, 2009; Karasar, 2005). In correlational survey study, e-learning attitudes were determined as dependent variables and digital citizenship behaviors were determined as independent variables.

\section{Sample Group}

The study group of this research consisted of education faculty students of a private university located in the Northern part of Cyprus. The universe of the study consisted of 120 people who studied at spring semester of 2019-2020 academic year. As the population of the universe was low, the entire universe was included in the study group. However, as participation was on voluntary basis, 105 people participated in the study. The distribution of students according to gender is as follows: 24 male and 64 female.

\section{Data Collection Process}

Two data collection tools were used in the study. In order to determine the digital citizenship behaviors of the participants, the Digital Citizenship Behavior Scale (DCB) developed by Akcil (2015) and the "Attitudes towards E-learning Scale (ELA) for Faculty of Education Students" developed by Haznedar and Baran (2012) were used. The ELA scale was obtained from the website https://toad.halileksi.net/ and used with the necessary permissions. It is seen that Cronbach $\alpha$ reliability coefficient calculated while developing both

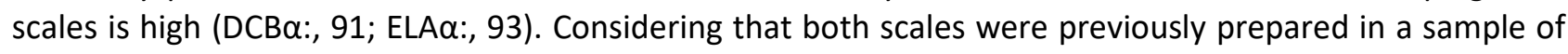
education faculty students, it is understood that these scales can be used in the study. In addition, five expert opinions were consulted to ensure the content validity. According to the opinions received, it was concluded that both scales could be applied.

The data collection tools to be used were organized in a certain order. First, DCB scale consisting of 39 questions was used. Then ELA scale consisting of two factors and 20 questions was employed. Finally, a form (PIF) was used to determine various personal characteristics and attitude of students towards e-learning during the current pandemic process. DCB and ELA are 5-point Likert type scales 
The scales were formed through Google Forms program so that they could be answered online. Then the relevant online form link was shared with students through course management system and they were asked to fill in the form. The collected data were downloaded to a computer through excel program and was subjected to error debugging process. After this process the data were uploaded to SPSS program and analysis was made.

\section{Data Analysis}

Accuracy of data obtained from data collection tools: First, the answers given by 105 participants who voluntarily participated for this process were examined. The data obtained from Google Forms program were organized into an excel document. By examining the "Timestamp" column, the average value of the time spent by the participants to fill out the 3-part form (DCB + ELA + PIF) was calculated. It was calculated that the average time spent by the participants who filled the form completely was 17:47 (min: sec). While filling out the form completely, it was understood that 17 participants, who spent much less time than this period, did not show enough care in answering the questions. For this reason, their answers were removed from the analysis unit. Thus, the data set consisting of 88 data was loaded into the SPSS 24.0 program.

Table 1. Timestamp of answers

\begin{tabular}{lc}
\hline & Timestamp \\
\hline Mean & $17: 47: 05$ \\
Max & $21: 02: 09$ \\
Min & $14: 47: 28$ \\
\hline
\end{tabular}

Normal distribution of data: Normal distribution test was applied to the data in SPSS program. However, since 10 of the 20 questions in the ELA scale were negative, the data in these questions were reverse-coded. The total values of the available data were calculated. If the data set was smaller than 50 , Shapiro-Wilk test results were taken into account, and if it was greater than 50, the results of the Kolmogorov Smirnov normality test were taken into account (Büyüköztürk, 2020). In the next step, the $Q-Q$ chart was examined to examine the normal distribution of the data. Table 1 and Figure 1 show a normal distribution of the data.

Table 2. Test of normality

\begin{tabular}{lcccccc}
\hline & \multicolumn{3}{c}{ Kolmogorov-Smirnov $^{\mathrm{a}}$} & \multicolumn{3}{c}{ Shapiro-Wilk } \\
\hline & Statistic & $\mathrm{df}$ & Sig. & Statistic & $\mathrm{df}$ & Sig. \\
Digital Citizenship Behavior & .048 & 88 & $.200^{*}$ & .988 & 88 & .603 \\
E-learning Attitude & .076 & 88 & $.200^{*}$ & .991 & 88 & .821 \\
\hline
\end{tabular}
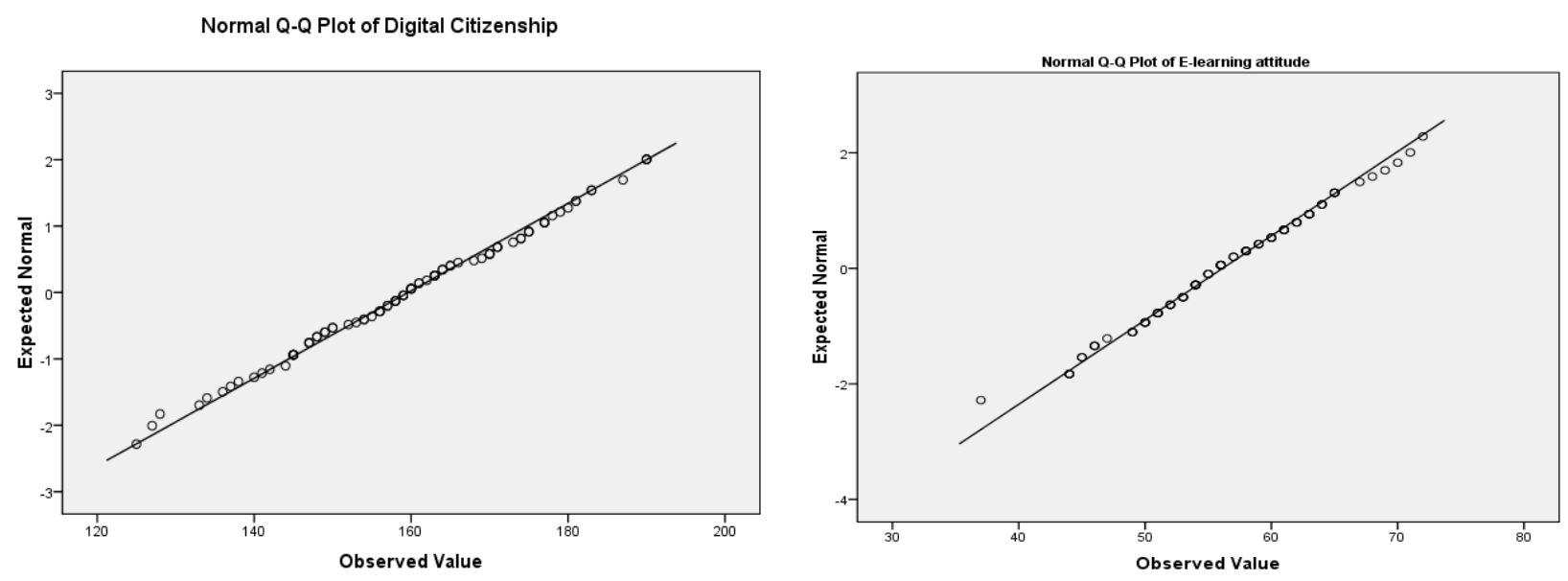

Figure 1. $Q-Q$ chart

Repeat reliability tests: Before moving on to the analysis of the research questions determined in this study, the reliability coefficient of all data according to the scales (Cronbach alpha ' $\alpha$ ') and the reliability coefficient of the scale sub-dimensions were calculated again and given in Table 3. As seen in Table 3, all values are within acceptable reliability range (Mean: ' $X$ ', number of item: "N", $\alpha: 60$ ). 
Table 3. Reliability statistics

\begin{tabular}{lccc}
\hline & $\overline{\mathbf{X}}$ & $\mathbf{N}$ & $\boldsymbol{\alpha}$ \\
\hline Total of digital citizenship & $\mathbf{4 . 0 9}$ & $\mathbf{3 9}$ & .83 \\
Factor 1: Digital literacy & 3.80 & 5 & .67 \\
Factor 2: Digital rights and responsibilities & 4.19 & 6 & .70 \\
Factor 3: Digital communication & 4.14 & 3 & .64 \\
Factor 4: Digital security/safety & 3.97 & 3 & .64 \\
Factor 5: Digital commerce & 4.12 & 4 & .87 \\
Factor 6: Digital interaction/access & 4.28 & 3 & .63 \\
Factor 7: Digital ethics & 3.96 & 4 & .60 \\
Factor 8: Digital health & 4.09 & 3 & .61 \\
Factor 9: Using portable smart devices & 4.53 & 4 & .76 \\
Factor 10: Use of digital storage(cloud) areas & 3.73 & 4 & .80 \\
\hline Total of e-learning attitude & $\mathbf{2 . 9 0}$ & $\mathbf{2 0}$ & .61 \\
Factor 1: E-learning predisposition & 3.27 & 10 & .93 \\
Factor 2: Avoiding e-learning & 2.33 & 10 & .89 \\
\hline
\end{tabular}

Applied tests: It was observed that the data was distributed normally and parametric tests were used. Among these tests, the Pearson correlation test was used to examine the relationship between the dependent independent variable, the T-test and ANOVA test were used to examine whether there is a difference between the independent variables and the averages of the total scores obtained from the scales, and frequency test and graphics were used to reveal the general belief level for the e-learning process. In the study, the reliability level $(*) .05$ was taken into consideration in the significance tests. In the interpretation of the correlation analysis, the coefficient ranges between $0.70-1.00$ are considered as high correlation, between 0.70-0.30 as medium correlation, and between 0.30-0.00 as low correlation (Büyüköztürk, 2020).

\section{RESULTS}

The first question of the study was determined as "What is the level of attitudes of students towards elearning during the COVID-19 pandemic?" and the second question was determined as "What is the level of the digital citizenship behaviors of students?" Descriptive analysis test (Mean: "X" Standard Deviation: "SD") was used to search for an answer to this question. In this framework, the findings are seen in Table 4.

Table 4. Total score distribution from scales

\begin{tabular}{lcccccc}
\hline & $\mathbf{N}$ & Range & Min & Max & $\overline{\mathbf{X}}$ & SD \\
\hline DCB & 88 & 65.00 & 125.00 & 190.00 & 159.61 & 15.19 \\
ELA & 88 & 35.00 & 37.00 & 72.00 & 56.13 & 6.85 \\
\hline
\end{tabular}

As can be seen in Table 4, it is revealed that the digital citizenship behavior (DCB) level of students is quite high $(\bar{X}=159,61)$. This value can be shown as $\bar{X}=4.09$ on a 5 -scale rating. It can be argued that the students have digital citizenship behaviors and they show these behaviors. It is seen that e-learning attitudes (ELA) of students are at a medium level $(X=56.13)$. This value can be shown as $\bar{X}=2.90$ on a 5 -point scale. It can be said that e-learning attitudes of students are lower than their digital citizenship behaviors. This finding will be examined under further analysis.

The third question of the study is given as "is there a relationship between attitudes of students towards elearning and their digital citizenship behaviors in the COVID-19 process?" Correlation tests were used in answering this question. Findings are given in Table 5.

Table 5. Pearson Corelations anlaysis

\begin{tabular}{lccc}
\hline Variables & & DCB & ELA \\
\hline DCB & $\mathrm{r}$ & 1 & $.322^{* *}$ \\
& $\mathrm{p}$ & & .002 \\
& $\mathrm{~N}$ & 88 & 88 \\
\hline ELA & $\mathrm{r}$ & $.322^{* *}$ & 1 \\
& $\mathrm{p}$ & .002 & 88 \\
\hline
\end{tabular}

\footnotetext{
**. Correlation is significant at the 0.01 level (2-tailed).
} 
As can be seen in Table 5, there is positive and medium level correlation $(r=0.322 ; p<0.01)$ between digital citizenship behaviors (DCB) and e-learning attitudes (ELA). In other words, digital citizenship behaviors positively affect e-learning behaviors of students. Although this analysis does not give a cause-effect relationship, it can be mentioned that there is a certain effect. It was also checked whether the intermediate level of correlation that emerged as a result of the analysis changes with the effect of various environmental variables. Table 6 can be examined for relevant findings.

Table 6. Partial Corelations Analysis

\begin{tabular}{llccc}
\hline Control Variable & & & DCB & ELA \\
\hline 1 & DCB & $\mathrm{r}$ & 1 & .408 \\
& & $\mathrm{p}$ &. & .000 \\
& & $\mathrm{r}$ & .408 & 1 \\
\cline { 2 - 5 } & ELA & $\mathrm{p}$ & .000 &. \\
& & $\mathrm{df}$ & 84 & 0 \\
\hline
\end{tabular}

1: COVID-19 belief status about being successful or not

When the Table 6 is examined, it can be observed that in the process of transition from full face-to-face education to full online education, the belief level of students as to whether they would be successful, is increased based on the results. This shows the correlation between total scores of variables $(r=0.408$; $\mathrm{p}<0.01)$. This finding indicates that when various environmental variables are taken under control, it can be said that digital citizenship behaviors will affect e-learning positively and with an increasing acceleration. However, the small size of data set can be the reason for the below-expected level of change.

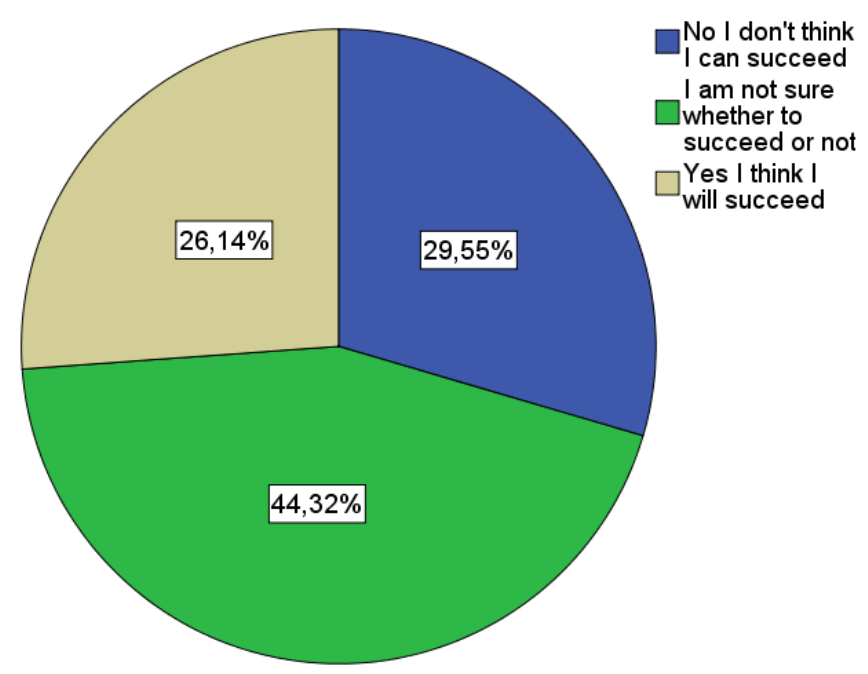

Figure 2. Belief in success for e-learning in the pandemic

The final question of the study was determined as "During the COVID-19 pandemic process, do the attitudes of students towards e-learning vary according to their gender and grade level, which are personal characteristics?" Anova and T-test was used to find answer to this question.

Table 7. T-test according to the gender of variables

\begin{tabular}{|c|c|c|c|c|c|c|c|}
\hline & Groups & $\mathbf{N}$ & $\overline{\mathbf{x}}$ & SD & $\mathbf{F}$ & $p$ & Difference \\
\hline \multirow[t]{2}{*}{$\mathrm{DCB}$} & Male & 24 & 156.20 & 13.10 & \multirow{2}{*}{1.968} & \multirow{2}{*}{.146} & \multirow{2}{*}{$p>.05$} \\
\hline & Female & 64 & 160.95 & 15.79 & & & \\
\hline \multirow[t]{2}{*}{ ELA } & Male & 24 & 55.20 & 6.43 & \multirow{2}{*}{.434} & \multirow{2}{*}{.424} & \multirow{2}{*}{$p>.05$} \\
\hline & Female & 64 & 56.48 & 7.02 & & & \\
\hline
\end{tabular}

When Table 7 is examined, it can be seen that there is no significant difference between digital citizenship behaviors (DCB) and e-learning attitudes (ELA) of students according to their gender. 
Table 8. Anova test according to the grade level of variables

\begin{tabular}{llccccc}
\hline Variables & & Sum of Squares & $\mathrm{df}$ & Mean Square & $\mathrm{F}$ & $\mathrm{p}$ \\
\hline DCB & Between Groups & 296.323 & 3 & 98.774 & .419 & .740 \\
& Within Groups & 19782.540 & 84 & 235.506 & & \\
& Total & 20078.864 & 87 & & & \\
\hline ELA & Between Groups & 425.723 & 3 & 141.908 & 3.251 & $.026 *$ \\
& Within Groups & 3666.640 & 84 & 43.650 & & \\
& Total & 4092.364 & 87 & & & \\
\hline$* 05$ & & & & &
\end{tabular}

When Table 8 is examined it can be seen no significant difference was found between grade level of students and their digital citizenship behavior. However, significant difference was detected between e-learning attitudes and grade level of students $(p=0.26, p<.05)$. Detailed analysis of the difference found was conducted. For this purpose, the Scheffe test, one of the post-hoc tests, was used. This test is the most commonly used test in multiple comparisons. It does not take into account the assumption that the number of observations in the groups is equal. The resulting difference was found to be between $1^{\text {st }}$ and $3^{\text {rd }}$ graders $(p<.38)$. It is seen that the average score $(\bar{X}=58.82)$ of the third graders is higher than the average score of the first graders $(\bar{X}=53.66)$. According to this result, it is understood that $3^{\text {rd }}$ graders' attitudes towards elearning are higher than that of $1^{\text {st }}$ graders. The fact that students in the first step of the school year are just getting acquainted with more complex distance education systems at university level may have reduced their e-learning attitudes. In addition, due to the sudden outbreak of COVID-19 pandemic, it can be said that these students were included in the distance education process before they were ready for e-learning.

\section{DISCUSSION}

This study aimed at examining the correlation between e-learning attitudes and digital citizenship behaviors of university students in COVID-19 pandemic process and the investigation of this correlation from the perspective of several variables. According to the obtained findings, it is seen that students show digital citizenship behaviors. In addition, it has been observed that the e-learning attitude of students is positive at medium level. Among the reasons may be the unpreparedness for the pandemic. Several studies can be found which support this opinion. Findings obtained from this study have displayed that students were not prepared for an online learning experience in this pandemic process. Students either fear that they will face many difficulties while working online, or they think that academics will not be able to help enough in the process during the pandemic period (Emmanuel et al., 2020). In addition, students abstain from assessment methods. Student assessment evaluation methods should be diversified and it should be ensured that students gain self-learning skills (Sarı \& Nayır, 2020).

All these indicators in past studies have showed up in this study as well. When the belief of students that they would not be successful in e-learning in the process of transition from face-to-face education to full online education are checked, it can be seen that a majority of students suffer from the sense of "uncertainty".

When the digital citizenship behaviors of students are examined, it can be seen that they show these behaviors at a high level. In the past research findings conducted with teacher candidates, it has been determined that digital citizenship levels are high (Kocadağ, 2012). As a result of these behaviors, students can continue their e-learning processes in the most positive way in the pandemic process. However, for this, the level of belief that they will be successful should be preserved and, in this period of panic, negative psychology should be quickly eliminated.

It is important that e-learning method, which developed and spread rapidly with the advances in technology, are examined from different perspectives and applied in the most accurate manner. In this direction, this study examined the impact of digital citizenship behaviors on e-learning. According to the obtained results, it has been concluded that digital citizenship behaviors affected e-learning attitudes in a positive manner. In another study, it was concluded that perceptions of pre-service teachers of digital citizenship were positive, and their readiness for e-learning was high (Kabataş, 2019). 


\section{CONCLUSION \& RECOMMENDATION}

E-learning attitudes of students thought to affect their desire for continuing education. High-quality learning experience of students does not only result from the efforts of teachers in e-learning (Haznedar \& Baran, 2012). Readiness and characteristics of students are extremely important (Simonson et al, 2009). It can be said that one of these important characteristics is digital citizenship behaviors. In COVID-19 pandemic process, the importance of digital citizenship behaviors, which are useful for opening to digital world and proceeding in a safe manner, has been revealed once again.

For faculty students and lecturers, online learning is believed to be more sustainable while instructional activities will become more hybrid provided the challenges experienced during this pandemic are well explored and transformed to opportunities (Abdedoyin \& Soykan, 2020). Lecturers and university managers must raise the technology usage capabilities as regards e-learning to the maximum level in the distance education venture of students (Azlan et al., 2020). At this point, COVID-19 pandemic process can be overcome more easily by elevating the digital citizenship behaviors of students and teachers to the next level.

\section{REFERENCES}

Adedoyin, O. B., \& Soykan, E. (2020). COVID-19 pandemic and online learning: the challenges and opportunities. Interactive Learning Environments. https://doi.org/10.1080/10494820.2020.1813180

Akcil, U., Altinay, Z., \& Altinay, F. (2016). Assessing the effects of managers in the digital age on the management process of digital citizenship roles. The Anthropologist, 23(1-2), 209-217. https://doi.org/10.1080/09720073.2016.11891943

Akcil, U., Altinay, Z., Dagli, G., \& Altinay, F. (2019). The 15th International Scientific Conference eLearning and Software for Education Bucharest, April 11-12.

Angoletto, R., \& Queiroz, V. C. (2020). COVID-19 and the challenges in education. The Centro de Estudos Sociedade e Tecnologial (CEST), 5, 2.

Avolio, B. J., Kahai, S., \& Dodge, G. E. (2000). E-leadership: Implications for theory, research, and practice. The Leadership Quarterly, 11(4), 615-668. https://doi.org/10.1016/S1048-9843(00)00062-X

Azlan, C. A., Wong, J. H. D., Tan, L. K., Huri, M. S. N. A., Ung, N. M., Pallath, V., \& Ng, K. H. (2020). Teaching and learning of postgraduate medical physics using Internet-based e-learning during the COVID-19 pandemic-A case study from Malaysia. Physica Medica, 80, 10-16. https://doi.org/10.1016/j.ejmp.2020.10.002

Basilaia, G., \& Kvavadze, D. (2020). Transition to Online Education in Schools during a SARS-CoV-2 Coronavirus (COVID-19) Pandemic in Georgia. Pedagogical Research, 5(4), em0060. https://doi.org/10.29333/pr/7937

Belonovskaya, I. D., Matvievskaya, E. G., Saitbaeva, E. R., Ksenofontova, A. N., Usmanov, S. M., Zatsepina, M. B., \& Bakshaeva, E. V. (2020). Digital Communication in Educational Process: Development Trends and New Opportunities. Online Journal of Communication and Media Technologies, 10(2), e202008. https://doi.org/10.29333/ojcmt/7928

Burke, J., \& Dempsey, M. (2020). COVID-19 Practice in primary schools in Ireland report. National University of Ireland Maynooth, Ireland. https://www.into.ie/app/uploads/2020/04/COVID-19-Practice-inPrimary-Schools-Report1.pdf.

Büyüköztürk, Ş., Akgün, Ö. E., Demirel, F., Karadeniz, Ş., \& Çakmak, E. K. (2020). Bilimsel araştırma yöntemleri [Scientific research methods] (28th ed.). https://doi.org/10.14527/9789944919289

Casey, D. M. (2008). The Historical Development of Distance Education Through Technology (Vol. 52). USA: TechTrends. https://doi.org/10.1007/s11528-008-0135-z 
Creswell, J. W. (2011). Controversies in mixed methods research. The Sage handbook of qualitative research, 4, 269-284.

Çubukcu, A., \& Bayzan, Ş. (2013). Türkiye'de dijital vatandaşlık algısı ve bu algıyı internetin bilinçli, güvenli ve etkin kullanımı ile artırma yöntemleri [Digital citizenship perception in Turkey and methods of increasing this perception with the conscious, safe and effective use of the Internet]. Middle Eastern \& African Journal of Educational Research, 5, 148-174.

Daniel S. J. (2020). Education and the COVID-19 pandemic. Prospects, 49, 91-96. https://doi.org/10.1007/s11125-020-09464-3

Demir, E. (2014). Overview of distance education. Dumlupınar University, Journal of Social Sciences, 39, 203212.

Demuyakor, J. (2020). Coronavirus (COVID-19) and Online Learning in Higher Institutions of Education: A Survey of the Perceptions of Ghanaian International Students in China. Online Journal of Communication and Media Technologies, 10(3), e202018. https://doi.org/10.29333/ojcmt/8286

Deshmukh, S. R. (2020). Social Realities of Higher Education in the Age of Uncertainties. Smart Moves Journal IJELLH, 8(4), 279-289. https://doi.org/10.24113/ijellh.v8i4.10547

Education, A. (2012). Digital citizenship policy development guide. ERIC Clearinghouse.

Firat, M. (2016). 21. Paradigm Shift in Distance Education in the 21st Century. Journal of Higher Education \& Science, 6(2). https://doi.org/10.5961/jhes.2016.151

Fraenkel, Jack R., \& Wallen, Norman E. (2009). How to design and evaluate research in education (7th ed.). New York: McGraw-Hill.

Gong, R. (2020). Coping with COVID-19: Distance Learning and the Digital Divide. Kri Views 21/20.

Gulbahar, Y. (2012). E-ogrenme. Ankara: Pegem Akademi Yayinevi.

Haznedar, Ö., \& Baran, B. (2012). Eğitim fakültesi öğrencileri için e-öğrenmeye yönelik genel bir tutum ölçeği geliştirme çalişmasi. Eğitim Teknolojisi Kuram ve Uygulama, 2(2), 42-59. https://doi.org/10.17943/etku.84225

Kabataş, S. (2019). Öğretmen adaylarının dijital vatandaşlık algılarının yaşam boyu öğrenme tutumları ve eöğrenmeye hazır bulunuşluğu açısından değerlendirilmesi [Evaluation of pre-service teachers' perceptions of digital citizenship in terms of lifelong learning attitudes and readiness for e-learning] (Unpublished Masters' Thesis), Bartın University, Institute of Education Sciences.

Karaatmaca, C., Altinay, F., Altinay, Z., Dagli, G., \& Akcil, U. (2020). Fostering digital citizens: perceptions of sensitivity training. The International Journal of Information and Learning Technology. https://doi.org/10.1108/IJILT-03-2020-0034

Karasar, N. (2005). Araştırma yöntemleri [Research methods]. Ankara: Nobel yayıncılık.

Kocadağ, T. (2012). Öğretmen adaylarının dijital vatandaşılı düzeylerinin belirlenmesi [Determining the digital citizenship levels of prospective teachers] (Unpublished Masters' Thesis), Karadeniz Technical University, Department of Computer Education and Instructional Technology, Institute of Educational Sciences, Trabzon.

Lounis, M. (2020). Promoting School Health Education: A Lesson from the COVID-19 Pandemic. Contemporary Mathematics and Science Education, 1(2), ep20009. https://doi.org/10.30935/conmaths/8579

Moore, M., \& Kearsley, G. (1996). Distance Education. A Systems View. California: Wadsworth Publishing Co.

Mossberger, K., Tolbert, C. \&amp; McNeal, R.S. (2007). Digital Citizenship: The Internet, Society and Participation. London, England: The MIT Press. https://doi.org/10.7551/mitpress/7428.001.0001 
Muhammad, A., Ghalib, M. F. M. D., Ahmad, F., Naveed, Q. N., \& Shah, A. (2016). A study to investigate state of ethical development in e-learning. J. Adv. Comput. Sci. Appl, 7(4), 284-290. https://doi.org/10.14569/IJACSA.2016.070436

Mulenga, E. M., \& Marbán, J. M. (2020). Is COVID-19 the gateway for digital learning in mathematics education? Contemporary Educational Technology, 12(2), ep269. https://doi.org/10.30935/cedtech/7949

Murphy, L., Eduljee, N. B., \& Croteau, K. (2020). College Student Transition to Synchronous Virtual Classes during the COVID-19 Pandemic in Northeastern United States. Pedagogical Research, 5(4), em0078. https://doi.org/10.29333/pr/8485

Mutua, S. N., \& Ong'ong'a, D. O. (2020). Online News Media Framing of COVID-19 Pandemic: Probing the Initial Phases of the Disease Outbreak in International Media. European Journal of Interactive Multimedia and Education, 1(2), e02006. https://doi.org/10.30935/ejimed/8402

Naveed, Q. N., Muhammad, A., Sanober, S., Qureshi, M. R. N., \& Shah, A. (2017). A mixed method study for investigating critical success factors (CSFs) of e-learning in Saudi Arabian universities. Methods, 8(5). https://doi.org/10.14569/IJACSA.2017.080522

Ribble, M. (2011). Digital Citizenship in Schools (2nd Ed). Washington DC: The International Society for Technology in Education (ISTE).

Ribble, M., \& Bailey, G. (2007). Digital Citizenships In Schools. Washington: ISTE.

Rosenberg, M. J. (2001). E-Learning: Strategies for delivering knowledge in the digital age. New York: McGraw-Hill.

Sarı, T., \& Nayır, F. (2020). Education in the Pandemic Period: Challenges and Opportunities. Electronic Turkish Studies, 15(4).

Sarsici, E., \& Çelik, A. İ. (2019). A Model Proposal for Digital Transformation in Education. International 'Innovations in Education and Social Sciences' Virtual Symposium, 339.

Simonson, M., Schlosser, C., \& Hanson, D. (1999). Theory and distance education: A new discussion. American Journal of Distance Education, 13(1), 60-75. https://doi.org/10.1080/08923649909527014

Simonson, M., Smaldino, S., Albright, M., \& Zvacek, S. (2009). Teaching and Learning at a distance Foundations of distance education (4th ed.). Boston, MA: Pearson Education, Inc.

Teräs, M., Suoranta, J., Teräs, H., \& Curcher, M. (2020). Post-COVID-19 Education and Education Technology 'Solutionism': a Seller's Market. Postdigital Science and Education, 1-16. https://doi.org/10.1007/s42438-020-00164-x

Ünal, D. P. (2017). Digital Citizenship Elements in A Curriculum and Secondary School Students' States of Having Digital Citizenship Elements. Karaelmas Journal of Educational Sciences, 5(2), 180-195.

UNESCO. (2020). School closures caused by Coronavirus (COVID-19). UNESCO. https://en.unesco.org/COVID19/educationresponse).

Urdan, T. A. \& Weggen, C. C. (2000). Corporate E-learning: Exploring a New Frontier. Retrieved from www.lib.umi.com

WHO. (2020a). Past pandemics. Retrieved from http://www.euro.who.int/en/healthtopics/communicablediseases/influenza/pandemic-influenza/past-pandemics

WHO. (2020b). Coronavirus disease (COVID-19) Pandemic. World Health Organization. Retrieved from https://www.who.int/emergencies/diseases/novel-coronavirus-2019 
WHO. (2020c). WHO Coronavirus Disease (COVID-19) Dashboard. World Health Organization. Retrieved from https://COVID19.who.int/

Zhao, Y. (2020). COVID-19 as a catalyst for educational change. Prospects, 49, 29-33. https://doi.org/10.1007/s11125-020-09477-y

Correspondence: Umut Akcil, Associate Professor in the Faculty of Education at Near East University, Nicosia, Cyprus. E-mail: u.akcil@neu.edu.tr 